\title{
IAMJ
}

INTERNATIONAL

AYURVEDIC

MEDICAL JOURNAL

Case Report

ISSN: 2320-5091

Impact Factor: 6.719

\section{A REVIEW OF JALUKAVACHARANA (LEECH THERAPY) IN THE MANAGEMENT OF THROMBOSED HAEMORRHOIDS - CASE REPORTS}

\author{
Basima A.P. ${ }^{1}$, Rejani H. ${ }^{2}$, George M.J ${ }^{3}$ \\ ${ }^{1}$ Post graduate scholar, ${ }^{2}$ Professor, ${ }^{3}$ Professor and HOD, Department of Shalyatantra, VPSV Ayurveda College, \\ Kottakkal, Kerala, India
}

Corresponding Author: basimaedavanna@gmail.com

https://doi.org/10.46607/iamj3609052021

(Published Online: May 2021)

Open Access

(C) International Ayurvedic Medical Journal, India 2021

Article Received: 27/04/2021 - Peer Reviewed: 05/05/2021 - Accepted for Publication: 08/05/2021

Check for updates

\begin{abstract}
Haemorrhoids are dilated veins within the anal canal in the subepithelial region formed by radicles of superior, middle and inferior rectal veins. It is a common ano-rectal disease. Thrombosed hemorrhoid is a painful swelling in the anal tissues caused by a clot in one or more small veins in the anal canal. According to modern science, there are many operative and non-operative procedures for the management of haemorrhoids. Most of the operative procedures are not patient friendly, cause high economic burden and associated with complications like pain, bleeding and recurrence. Acharya Vagbhata defines Arsas (haemorrhoids) as an abnormal growth which obstructs the anal canal and troubles continuously like an enemy. Shalyatantra deals with Sastra karma (surgical procedures), Anusastra karma (parasurgical procedures) and conservative management in the different types of diseases. Jaluka is considered as best among Anusastra. Acharya Vagbhata indicates Jalukavacharana in haemorrhoids when they are hard and swollen. The present article deals with Jalukavacharana in two patients having thrombosed haemorrhoids attended in outpatient department of VPSV Ayurveda College Kottakkal. Application of Jaluka (leech) provided improvement in features like pain, edema, tenderness and discoloration of mass.
\end{abstract}

Keywords: Thrombosed haemorrhoids, Arsha, Raktamokshana, Jalukavacharana. 


\section{INTRODUCTION}

Thrombosed haemorrhoid is a painful swelling in the anal tissues caused by a clot or thrombus in one or more small veins in the anal canal. It is a common acute anorectal disease, which hampers the routine life of an affected person.

Haemorrhoids are known as Arsas in Ayurveda. It is one among Ashta mahagada (eight severe diseases). Acharya Vagbhata defines Arsas as an abnormal growth which obstructs the anal canal and troubles continuously like an enemy ${ }^{1}$. The exact causes of haemorrhoids are unknown. Several contributory anatomical factors have been implicated; including chronic constipation, chronic diarrhoea, straining during bowel movement, irregular bowel habits, pregnancy, prolonged sitting, prolonged travelling, upright posture of human, ageing, heredity, obesity, derangement of internal anal sphincter, abdominal tumours and cancer of rectum ${ }^{2-4}$.

Thrombosed haemorrhoids are clot forming engorgement of blood vessels at anal orifice ${ }^{5}$ Which is usually very painful and extremely uncomfortable. It is commonly seen in external haemorrhoids. The clinical features of thrombosed haemorrhoids are pain during sitting, walking and defecating and to be worst during the first 24-48 hours. Other features are bleeding during defecation, itching around the anus, swelling or lumps around the anus with severe tenderness. Thrombosed haemorrhoids have complications like excessive bleeding per rectum, strangulation, gangrene and fibrosis, if remain untreated for long time. According to modern science, the treatment for thrombosed haemorrhoid is incision and drainage under local anaesthesia. Now a days many are reluctant to undergo surgical procedure and they expect relief without surgery because it may cause many complications such as bleeding, pain, anal stenosis, incontinence and infection.

Acharya Susruta mentions four therapeutic measures for the management of Arsas (haemorrhoid). They are Bheșhaja (internal medicines), Kṣhara karma (chemical cauterization), Agni karma (thermal cauterization) and Sastra karma(surgery) ${ }^{6}$. He also indicated Visravana or Raktamokshana (bloodletting) when the haemorrhoids are prolapsed (Nirgatani) and thrombosed (Doshapurnani). Acharya vagbhata says that the Jalukavacharana is the choice when the haemorrhoids are Uchoona (swollen) and Katina (hard).

This case study conducted in two patients, Jalukavacharana was done in 2 sittings with two days interval along with internal medications and sitz bath for 2 weeks. Follow up was done for three weeks. These case study reports show that Jalukavacharana is found to be safe and effective in thrombosed haemorrhoids.

\section{Plan of Work}

Two patients having complaint of thrombosed pile mass were selected from the outpatient department (OPD) of VPSV Ayurveda College Kottakkal. Before the treatment, blood routine, CT, BT, HIV, HBsAg were done and found within normal limits. Jalukavacharana was done in two sittings with a gap of two days in both the patients. Assessment of pain, edema, tenderness and discoloration was done and recorded.

\section{Leech Application}

The following procedures were conducted in both the patients in the same manner.

Purva Karma: An informed consent was obtained from the patient; the patient was advised to lie down in lithotomy position. The perianal area was cleaned with warm water and then wiped with a cotton swab. The selected leech was placed in a vessel containing water mixed with Haridra (Turmeric) powder till it became active. Then it was washed in fresh water.

Pradhana Karma: The activated leech was placed on the thrombosed pile mass and left undisturbed to hold on to the area. Then the leech was covered with a wet cotton and observed carefully up to 45 minutes. In both the cases, the leeches got detached by itself nearly at the end of 45 minutes.

Paschat Karma: The perianal part was cleaned with fresh water followed by application of Yashtichoorna (Glycirrhiza glabra). Then pressure bandage was done. The Jaluka was kept in a tray and Haridra powder was sprinkled over it to induce vomiting and massage was done from tail to head. After complete expulsion of blood, the leech was washed with water and kept in the container. 
The same procedure was repeated after two days by using another Jaluka.

Assessment of pain, edema, tenderness and discoloration was done and recorded on $4^{\text {th }}$ and $7^{\text {th }}$ day. Regular follow up was advised once in a month up to a period of three months.

\section{CASE REPORT}

\section{CASE1}

A male patient aged 43 years having complaints of protrusion of mass for the past 6 months on anal verge. He had severe pain for 2 days. On examination, thrombosed external pile masses were seen on 3, 7 and $11 \mathrm{o}$ ' clock position. A largest one was at $11 \mathrm{o}$ ' clock position. Jalukavacharana was done on throm-

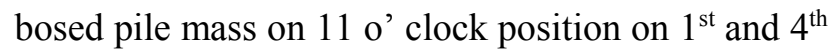
day.

\section{CASE2}

A male patient aged 53 years having complaints of protrusion of mass on anal verge along associated with severe constipation and pain since 4 days. He had history of first-degree internal pile mass since one year. On examination intero-external pile masses were seen on 3, 7 and 11 o' clock position. Thrombosed pile mass was seen on 7 o' clock position. Jalukavacharana was done on thrombosed pile mass on $7 \mathrm{o}^{\prime}$ clock position on $1^{\text {st }}$ and $4^{\text {th }}$ day.

In both cases, following medicines were given internally 1-Red

and follow up was done up to 3 weeks.
1) Gandharva hastadi kasayam ( $15 \mathrm{ml} \mathrm{ks}+45 \mathrm{ml}$ water)-2 times before food for Anulomana (laxative)

2) Kankayana vatika (1-0-1)

3) Tab. Biogest (1-0-1)

4) Sitz bath adding Triphala kasaya and salt.

\section{Assessment}

The assessment was done on $1^{\text {st }}, 4^{\text {th }}$, and $7^{\text {th }}$ day in both cases. During each follow up, signs and symptoms were observed.

\section{Criteria of Assessment}

\section{Pain}

0 -Absent

1-During defecation

2-Present after defecation up to one hour

3-Continous pain after defecation for more than one hour

\section{Edema}

0 -Absent

1-Confined to pile mass

2-Developed up to adjacent perianal skin and subcutaneous tissue

\section{Tenderness}

0 -No tenderness

1-Little response to sudden pressure

2-Wincing face on superficial slight touch

3-Resist to touch and rigidity

\section{Discoloration}

0-No discoloration

2-Reddish blue

3-Bluish purple

\section{RESULTS AND DISCUSSION}

The results are tabulated below

\section{Table I}

\begin{tabular}{|c|c|c|c|c|c|c|}
\hline \multirow[t]{2}{*}{ Signs and symptoms } & \multicolumn{2}{|c|}{ First day (before treatment) } & \multicolumn{2}{|l|}{ Fourth day } & \multicolumn{2}{|l|}{ Seventh day } \\
\hline & Case1(Fig. I a) & Case2 (Fig. II a) & Case1 (Fig. I b) & Case2 & Case1 (Fig. I c) & Case2 (Fig. II b) \\
\hline Pain & 3 & 2 & 1 & 1 & 0 & 0 \\
\hline Edema & 2 & 1 & 1 & 1 & 0 & 0 \\
\hline Tenderness & 3 & 2 & 2 & 1 & 0 & 0 \\
\hline Discoloration & 3 & 3 & 3 & 1 & 0 & 0 \\
\hline
\end{tabular}




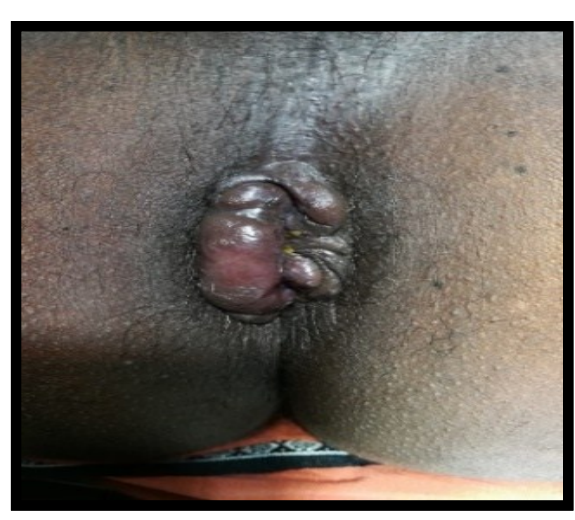

Fig. I a

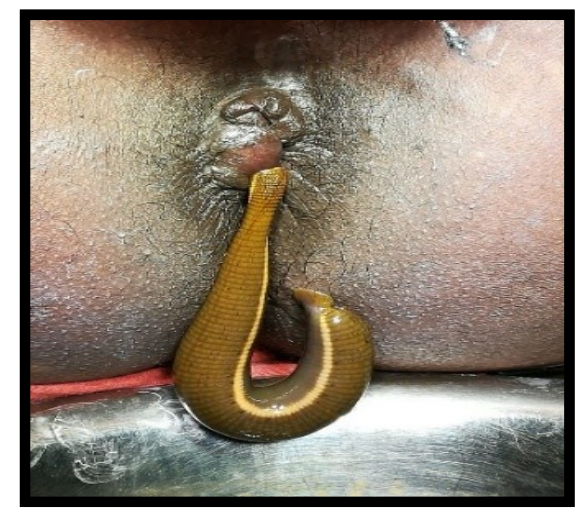

Fig. I b

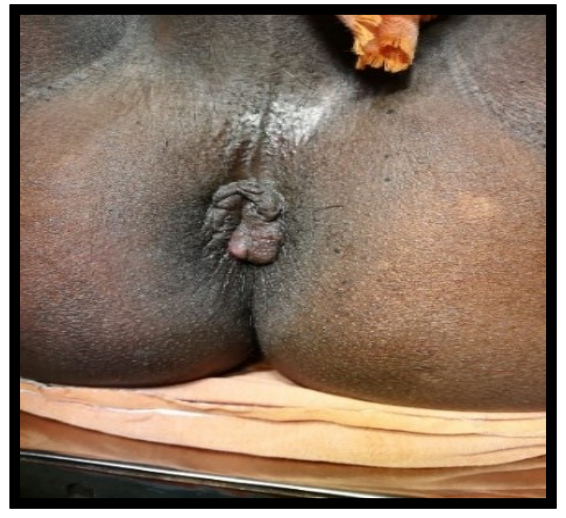

Fig. I c

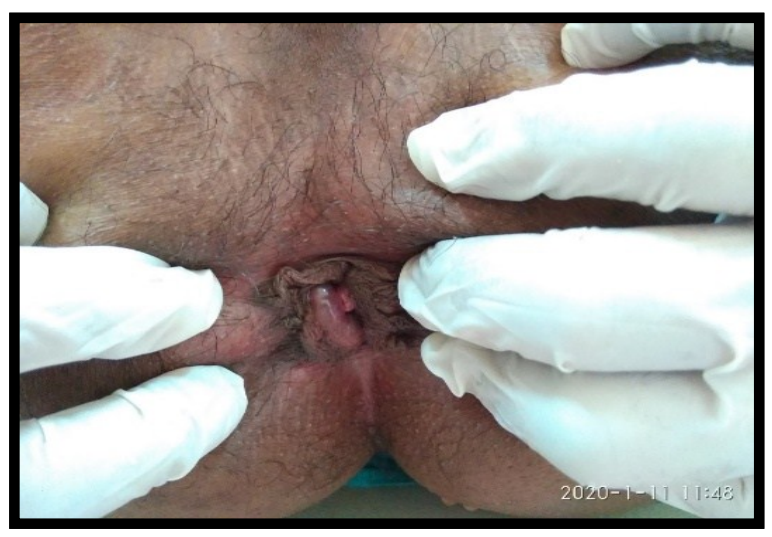

Fig. II a

Table I shows that on $7^{\text {th }}$ day, the signs and symptoms of both patients with thrombosed pile mass were relieved completely. During the follow up period there were no evidence of recurrence in both the patients. Engorgement of a hemorrhoidal vessel with acute swelling may allow blood to pool and, subsequently forming a clot; this leads to the acute thrombosed external hemorrhoid (TEH). Its appearance is bluish-purple discoloration often accompanied by severe incapacitating pain.

Raktamokshana is practiced in India since thousands of years, which has been included under the five bio-purificatory procedures. Leech application is one type of bloodletting in Ayurveda.

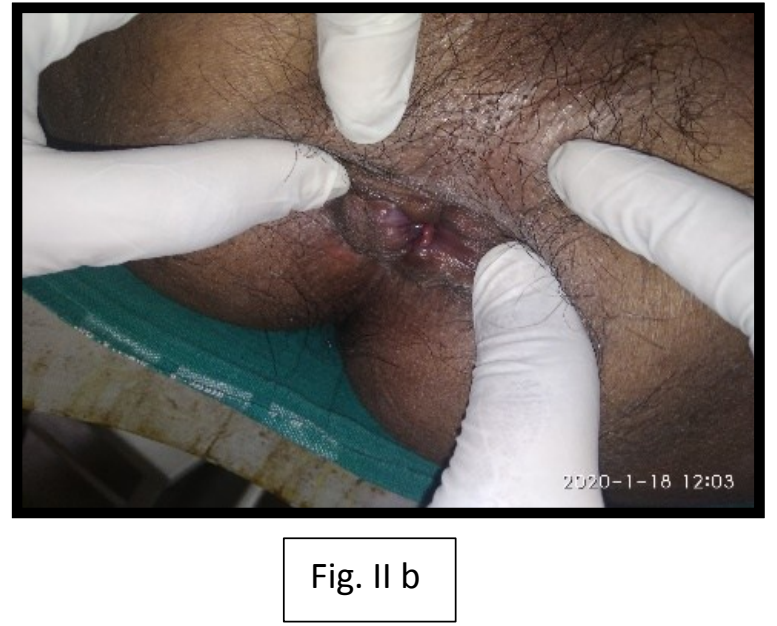

Saliva of leech contains more than hundred bioactive substances. One leech sucks 5 to $10 \mathrm{ml}$ of blood. Bleeding lasts for some hours (about 12-24 hours) and patient totally loses about $20-30 \mathrm{ml}$ of blood depending on the size of leech and saliva injected to the body.

In the above-mentioned cases, application of leeches results in the reduction of inflammation and pain due to anti-inflammatory substances present in the saliva of leech. Acc. to Ayurveda, Jalauka is indicated in Avagadha dosha dusti roga (doshas are at deeper level). During the process of jalukavacharana Saliva enters the deeper level of tissues by the action of hyalauronidase and hirudin (the factors of penetration). Which causes liquefaction of clotted blood. So, there was significant reduction in size of swelling of thrombosed haemorrhoid. 
Probable mode of action

\begin{tabular}{|c|c|c|}
\hline SI No & Constituent & Action \\
\hline 1 & $\begin{array}{l}\text { Hirudin } \\
\text { Bufrudin } \\
\text { Calin }\end{array}$ & $\begin{array}{l}\text { Anticoagulation } \\
\text { Hirudin is a naturally occurring polypeptides that prevents conversion of fibrinogen to fibrin } \\
\text { by inhibiting actions of thrombin resulting prevention of blood coagulation. } \\
\text { They accelerate the hematoma decongestion process. } \\
\text { Calin Inhibits blood coagulation by inhibition of collagen-mediated platelet aggregation and } \\
\text { adhesion. }\end{array}$ \\
\hline 2 & $\begin{array}{l}\text { Anaesthetic } \\
\text { substances }\end{array}$ & $\begin{array}{l}\text { Anaesthetic } \\
\text { The leech application is effective in reducing the pain due to anaesthetic action of leech } \\
\text { component. }\end{array}$ \\
\hline 3 & $\begin{array}{l}\text { Destabilase } \\
\text { Factor Xa inhibitor }\end{array}$ & $\begin{array}{l}\text { Thrombolytic } \\
\text { Destabilase has monomerizing activity and dissolves fibrin. } \\
\text { Factor Xa Inhibitor inhibits the activity of coagulation by forming equimolar complexes. } \\
\text { These factors promote reduction of swelling and dissolution of the organized blood-clots. }\end{array}$ \\
\hline 4 & Hyaluronidase & $\begin{array}{l}\text { Antibiotic } \\
\text { It breaks down the hyaluronic acid, increases interstitial viscosity and act as an Antibiotic. }\end{array}$ \\
\hline 5 & $\begin{array}{l}\text { Carboxypeptidase A } \\
\text { inhibitors } \\
\text { Histamine like sub- } \\
\text { stances } \\
\text { Acetylcholine }\end{array}$ & $\begin{array}{l}\text { Vasodilation and Microcirculation } \\
\text { Increases the inflow of blood at the bite site. } \\
\text { They ensure drainage by partially or totally replacing venous return. Because leeches are } \\
\text { particularly attracted to deoxygenated blood. } \\
\text { Through their sucking effect, leeches stimulate circulation of cells at risk of necrosis and } \\
\text { maintain oxygenation of the tissue. Therefore, promote restoration of capillary anastomosis } \\
\text { and neovascularization. }\end{array}$ \\
\hline 6 & $\begin{array}{l}\text { Bdellines } \\
\text { Eglins } \\
\text { Hirustasin }\end{array}$ & $\begin{array}{l}\text { Anti-inflammatory } \\
\text { Anti-inflammatory proteins. Inhibit the activity of alpha-chymotrypsin, chymase, substil- } \\
\text { isin, elastase and cathepsin G. } \\
\text { Bdellins inhibits trypsine and plasmin. } \\
\text { Hirustasin inhibits kallikrein, trypsin, chymotrypsin and neutropholic cathepsin G. }\end{array}$ \\
\hline
\end{tabular}

Gandharvahastadi kasaya mentioned in sahasrayoga contains Gandharvahasta (Ricinus communis), Chiribilva (Holoptelea integrifolia), Citraka(Plumbago zyelanica), Viswa (Zingeber officianalis), Pathya (Terminalia chebula), Punarnava (Boerrhavia diffusa), Yavasa (Alhagi psudalhagi) and Bhumitala (Phyllanthus niruri). All these herbs exhibit action as anti-inflammatory, analgesic and laxative. Most of them has Arsogna (anti haemorrhoidal) property. Triphala churna mentioned in Sharandhar Samhita and Bhavaprakasa (Haritakyadi varga) contains Amalaki (Emblica officinalis), Haritaki (Terminalia chebula) and Vibhitaki (Terminalia bellirica). Sitz bath with triphala choorna has ant-inflammatory action and also shows analgesic property by relieving venous congestion. Kankayana gutika mentioned in
Bhaishajyaratnavali and Gulma prakarana also has Arsogna property. Biogest tablet contains Guggulu (Comifora mukul), Raktapunarnava (Boerraavia diffusa), Haritaki (Terminalia chebula) and Bibhitaki (Terminalia bellerica). Which provides anti-inflammatory and decongestive action on thrombosed haemorrhoids. Leech application along with internal and external medications helps in reduction of swelling, inflammation, pain and early recovery of the patient. Here internal medicines were taken for three weeks in both cases after the procedure and dietary restrictions were followed during this period. We should always be careful in selection of leech to prevent complication due to allergic reactions and also during procedure to prevent the movement of leech into anal canal. 


\section{CONCLUSION}

Thrombosis of external haemorrhoid is a common acute complication of haemorrhoids. Patient experiences tense and tender swelling in perianal region. Usually it resolves within 15-21 days, but there is a chance of suppuration, bursting and fibrosis. Jalukavacharana was found to be safe and effective in the management of thrombosed haemorrhoid. There will be an immediate reduction in the size of swelling, pain and tenderness. During the follow up period of three months, no thrombosed haemorrhoids were found on anal verge. These case studies show that jalukavacharana on thrombosed haemorrhoids along with internal medicines and dietary modification was effective. This procedure is also cost effective and having less complications.

\section{REFERENCES}

1. Sharma P.V. Ashtangahrdayam (with the commentaries arunadatta and hemadri): varanasi: Chaukhamba Orientalia;2011: p 490.7/1

2. Rajasree G. Anorectal Disorders Āyurvedic Approach. Varanasi: Chaukambha Orientalia; 2015; P.16-71.

3. Lohsiriwat V. Treatment of hemorrhoids: A coloproctologist's view. World Journal of Gastroenterology: WJG. 2015 Aug 21;21(31):9245.

4. Loder PB, Kamm MA, Nicholls RJ, Phillips RK. Haemorrhoids: pathology, pathophysiology and aetiology. British Journal of Surgery. 1994 Jul;81(7):946-54.

5. Greenspon J, Williams SB, Young HA, Orkin BA. Thrombosed external hemorrhoids: outcome after conservative or surgical management. Diseases of the colon \& rectum. 2004 Sep;47(9):1493-8.

6. 6.Sharma P. V. Suśruta Saṃhita (with English translation and dalhana commentary): Varanasi: Chaukhamba Orientali;2010; volume 2 (chikitsa sthana): $p$ 328.6/2(Haridas Āyurvēda series).

7. Singh Sarika, Kedar Nita M, Raut Subhash Y, Lakhapati Arun M. Role of Jaloukavacharan in Thrombosed Hemorrhoids- A Case Study. Int. J. Ayur. Pharma Research. 2014;2 (3):100-103.

\section{Source of Support: Nil Conflict of Interest: None Declared}

How to cite this URL: Basima A.P et al: A Review of Jalukavacharana (Leech Therapy) In The Management Of Thrombosed Haemorrhoids - Case Reports. International Ayurvedic Medical Journal \{online\} 2021 \{cited May, 2021\} Available from: http://www.iamj.in/posts/images/upload/1152 1157.pdf 